\title{
Are Portuguese coastal fisheries affected by river drainage?
}

\author{
Rita Gamito $^{a}$, Catarina Vinagre, Célia M. TeiXeira, Maria J. Costa and Henrique N. Cabral \\ MARE - Marine and Environmental Sciences Centre, Faculdade de Ciências da Universidade de Lisboa, Campo Grande, \\ 1749-016 Lisboa, Portugal
}

Received 27 November 2015; Accepted 29 February 2016

\begin{abstract}
The Portuguese coast is particularly adequate for studies on the impact of climate change on fisheries, as it has faced an increase in both air and sea surface temperature and a decrease in intensity and frequency of rainfall. Ecological responses to climate change have already been observed in Portuguese waters, with consequences in fisheries. Regional climate models have predicted a further decrease in rainfall in Portugal by the end of the century, which will have a strong impact on the runoff into coastal areas. River drainage affects the physical, chemical and biological properties of coastal ecosystems, regulating habitat availability and favouring their productivity. The present study analysed the influence of river drainage on landings of coastal ports in the vicinity of four hydrologically distinct estuaries. Unlike previous results obtained for the Mediterranean, no significant relationships between river drainage and landings were found. Relationships between drainage and landings can be inconsistent among regions and dependent on how strongly a food web relies on nutrients and organic matter of river origin. In the Portuguese coast, an upwelling regime is of particular importance for the richness and diversity of the coastal ecosystem and for fisheries. The complexity of the coastal upwelling phenomenon together with a possible interaction of several other smaller scale factors acting on recruitment of commercial species may mask the effects of river drainage on landings. Nevertheless, as accentuated decreases in rainfall have been predicted for Portugal, the resulting reduction in river drainage may still strongly impact fisheries in the future.
\end{abstract}

Keywords: River drainage / coastal ecosystems / fisheries landings / climate change

\section{Introduction}

Climate change has been considered the most widespread anthropogenic threat for ocean ecosystems (Halpern et al. 2008), affecting sea temperature, sea-level, ocean $\mathrm{pH}$, rainfall and ocean circulation (Brander 2007). These effects of climate change on ocean conditions will have an impact on marine organisms, the composition of marine communities and ecosystem function, therefore affecting fisheries (Brown et al. 2010; Sumaila et al. 2011). Both predictions of climate change in future scenarios and recently observed impact of climate change indicate that the effects of climate change will not be homogeneous throughout the world (IPCC 2007) (Santos 2006). Southern Europe and the Mediterranean are more vulnerable to climate change than Central and Northern Europe (Santos 2006). The Iberian Peninsula is one of the areas where air temperature has increased most (IPCC 2007). Also, the Iberian Coastal large marine ecosystem has recently suffered a rapid warming, with an increase of $0.68{ }^{\circ} \mathrm{C}$ in sea surface temperature from 1982 to 2006 (Belkin 2009). The Portuguese coast is mainly North-South oriented and is located in a biogeographic transition zone, between temperate and subtropical waters,

\footnotetext{
${ }^{a}$ Corresponding author: rgamito@fc.ul.pt
}

where several temperate and subtropical fish species have their southern or northern distribution limit (Briggs 1974). Ecological responses to recent climate change have been observed in Portuguese waters (Cabral et al. 2001; Vinagre et al. 2009) and the rising sea surface temperature in the region has been linked to fisheries landings (Gamito et al. 2013, 2015; Teixeira et al. 2014). A decrease in the intensity and frequency of rainfall has also been observed in Portugal (IPCC 2007). Regional climate models predict a decrease of more than $30 \%$ in southern Portugal by the end of the century (Miranda et al. 2002). This decrease in rainfall will have an impact on the runoff of Portuguese rivers into coastal areas.

River runoff affects the physical, chemical and biological properties of coastal ecosystems (Gillson 2011). Changes in salinity, turbidity, temperature and sediment delivery caused by variations in river flow regulate habitat availability for fish and invertebrates in coastal areas (Gillson 2011). Furthermore, the productivity of coastal ecosystems may be favoured by terrestrial inputs from the runoff of adjacent rivers (Simenstad and Wissmar 1985). River water carries nutrients and organic matter of terrestrial origin into coastal ecosystems, which will enhance plankton production and deposit in benthos (Cloern 2001; Moutin et al. 1998). Also, terrestrial particulate organic matter (POM) is extremely important for the dynamics 
of coastal macrobenthic communities (Hermand et al. 2008; Salen-Picard and Arlhac 2002; Salen-Picard et al. 2002). As various marine commercial fish species have nursery grounds mainly located in estuarine and coastal areas (Cabral et al. 2007), they are affected by river water inputs. Terrestrial POM has been shown to be incorporated into higher levels of the food web, such as commercial fish species, in coastal areas adjacent to the Tejo estuary (Vinagre et al. 2011). Therefore, variations in river flow can have an indirect impact on coastal fisheries, through a trophic cascade (Darnaude 2005; Darnaude et al. 2004).

As the third highest per capita consumer of fish in the world, fisheries hold a great traditional and cultural importance in Portugal (Failler 2007). Three main fleet components operate in Portuguese fisheries: trawl fisheries, purse-seine fisheries and multi-gear fisheries. The largest fleet component in Portugal belongs to multi-gear fisheries, which comprise a wide variety of fishing gears, such as gill nets, trammel nets, longlines and traps. This mainly artisanal fleet targets a wide range of species along the coastal area of Portugal and the same multi-gear vessel can be licensed to operate with several different fishing gears. However, the main targets of this fishery are Solea spp., the common cuttlefish Sepia officinalis Linnaeus, 1758 and the common octopus Octopus vulgaris Cuvier, 1797.

As higher river drainage has previously been considered to increase fishery production (e.g. Darnaude et al. 2004; Le Pape et al. 2003; Salen-Picard et al. 2002), the aim of the present study was to analyse the influence of river drainage on landings of Portuguese fisheries, as well as the relative importance of other environmental variables. This study is of particular important in the context of climate change, given the predicted decrease in rainfall in Portugal (Miranda et al. 2002). As the variability observed in relationships between freshwater flow and landings of fish and invertebrates has previously been related with factors such as geographic location (Gillanders and Kingsford 2002) or estuarine geomorphology (Saintilan 2004), the present study focused on landings of coastal ports in the vicinity of four hydrologically distinct estuaries.

\section{Methodology}

\subsection{Study area}

Landings of ports in the vicinity of Minho, Ria de Aveiro, Mondego and Tejo estuaries were studied (Fig. 1). The hydrological characteristics of each estuary are presented in Table 1. The ports analysed were located in the coastal area adjacent to each estuary, within a radius of $20 \mathrm{~km}$.

\subsection{Data source}

Fishing data of local multi-gear fisheries were obtained from official Portuguese landings, covering the period of 1992 to 2012. Landing data included fishing port, species caught, year and number of fishing days. Sea surface temperature (SST) monthly data were collected from the International Comprehensive Ocean-Atmosphere Data Set (ICOADS)

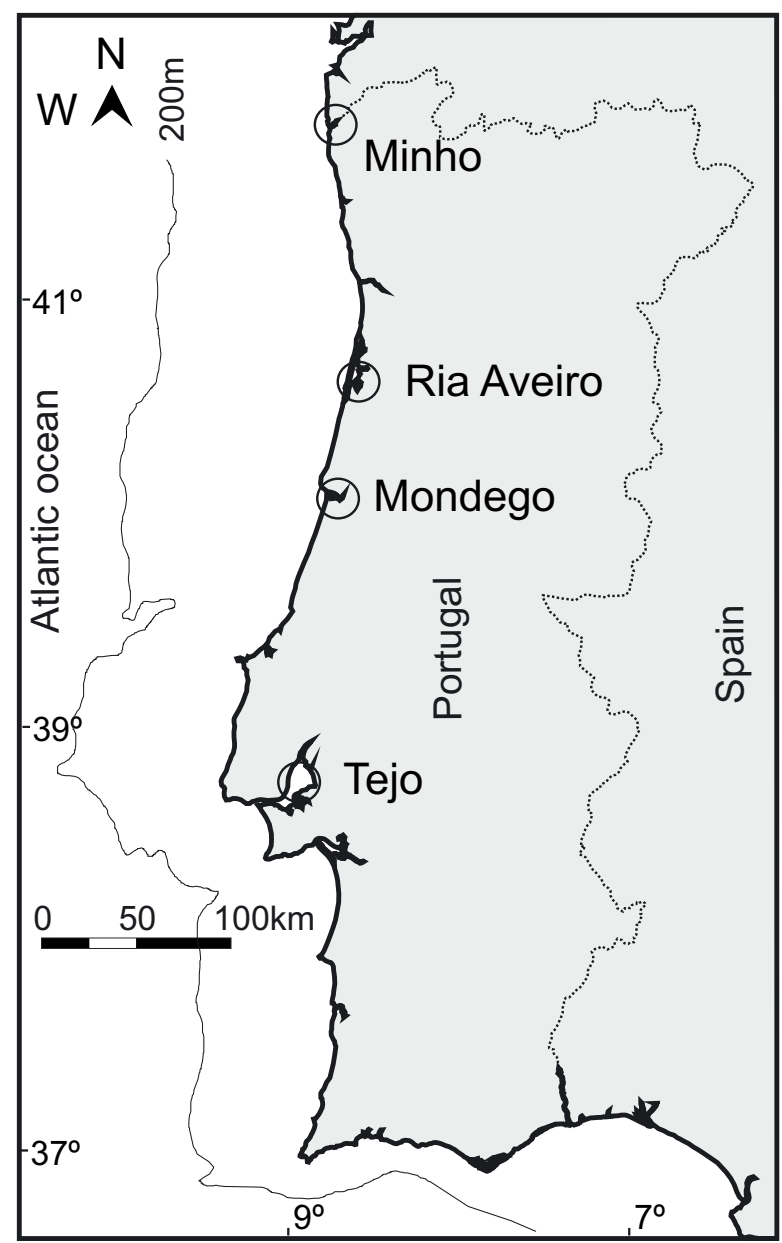

Fig. 1. Location of the studied areas on the Portuguese coast.

database (http://icoads.noaa.gov). Rainfall and river drainage monthly data were provided by the Portuguese Water Resources Information System (http://snirh.pt).

\subsection{Data analysis}

For each environmental variable, the values obtained for the rainiest months (November-March) were averaged. Landings Per Unit of Effort (LPUE) were calculated as t.day ${ }^{-1}$. LPUE of 6 commercial species/group of species with life cycles which are somewhat dependent on estuaries, either by using them as nurseries, either by living in their vicinity, were analysed: European seabass (Dicentrarchus labrax (Linnaeus, 1758)) seabreams (Diplodus spp.); European flounder (Platichthys flesus (Linnaeus, 1758)); soles (Solea spp.); common cuttlefish (Sepia officinalis Linnaeus, 1758) and common octopus (Octopus vulgaris Cuvier, 1797).

The LPUE of each species/group of species were modelled with generalized linear models (GLMs). GLMs are an extension of linear models that allow the incorporation of non-normal distributions of the response variable and its transformation to linearity (McCullagh and Nelder 1983). As LPUE data consist of positive values, log-normal or gamma distributions may be appropriate to the response variable 
Table 1. Hydrologic and geomorphologic characteristics of Minho, Ria de Aveiro, Mondego and Tejo estuaries.

\begin{tabular}{ccccccc}
\hline Estuary & $\begin{array}{c}\text { Total area } \\
\left(\mathrm{km}^{2}\right)\end{array}$ & $\begin{array}{c}\text { Mean river flow } \\
\left(\mathrm{m}^{3} / \mathrm{s}\right)\end{array}$ & $\begin{array}{c}\text { Mean depth } \\
(\mathrm{m})\end{array}$ & $\begin{array}{c}\text { Mean residence } \\
\text { time }(\text { days })\end{array}$ & $\begin{array}{c}\text { Entrance width } \\
(\mathrm{m})\end{array}$ & $\begin{array}{c}\text { Intertidal area } \\
(\% \text { of total area })\end{array}$ \\
\hline Minho & 24.5 & 300 & 3 & 2 & 1246 & 9 \\
Ria de Aveiro & 120.8 & 40 & 2 & 17 & 437 & 64 \\
Mondego & 8.6 & 79 & 2 & 3 & 264 & 64 \\
Tejo & 367.5 & 300 & 5 & 25 & 4909 & 40 \\
\hline
\end{tabular}

(a)

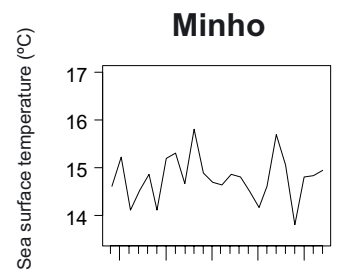

\begin{abstract}
Ria de Aveiro
\end{abstract}

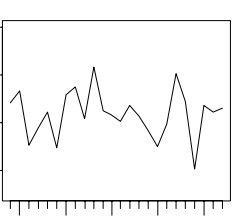

(b)

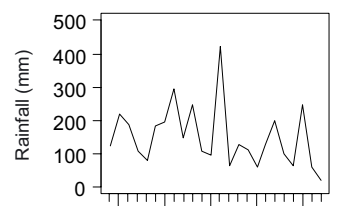

(c)

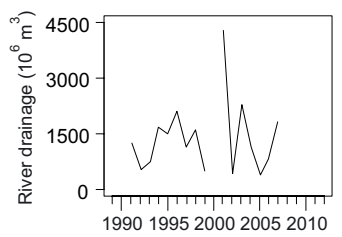

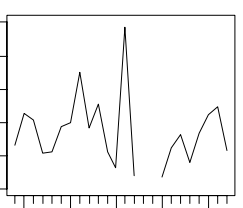

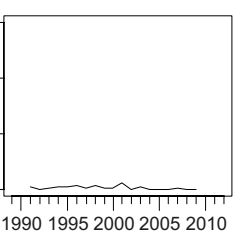

Tejo
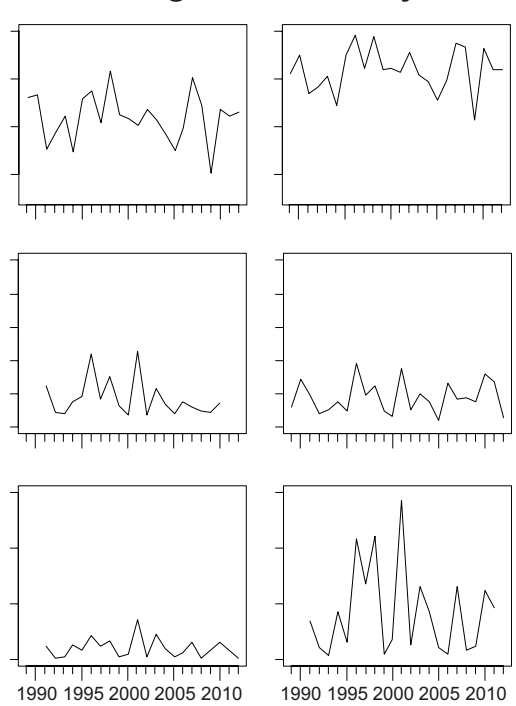

Fig. 2. Mean winter (November-March) sea surface temperature (a), rainfall (b) and river drainage (c), based on monthly data.

(Stefánsson 1996). However, gamma distribution has been considered more suitable for fisheries data (Maynou et al. 2003; Myers and Pepin 1990).

For each species' model, the response variable (LPUE) was modelled as a function of estuary, river drainage, and SST. Due to the existing gaps in river drainage data, and given the observed correlation between river drainage and rainfall (see Fig. 2), rainfall was used as a proxy of river drainage. The general model used was:

$$
\log (\mu)=\beta_{0}+\beta_{1} X_{1}+\ldots+\beta_{p} X_{p}
$$

where $\beta^{t}$ is the parameter set relating the descriptors $X_{p}$ to the response, using a log link function and a gamma distribution for the response variable. The effects of environmental variables are stronger on early life stages, influencing recruitment success and subsequently LPUE of later years. For that reason, time-lags based on the available knowledge on age at first maturity were considered: 2 years for seabreams (Benchalel and Kara 2013; Gonçalves et al. 2003; Gordoa and Moli 1997); 3 years for seabass, flounder and soles (Pawson et al. 2007; Teixeira and Cabral 2010; Teixeira et al. 2009, 2010); and 1 year for octopus and cuttlefish (Katsanevakis and Verriopoulos 2006a; Neves et al. 2009). The statistical significance of each descriptor was tested at a level of 0.05 . The goodnessof-fit of the models was assessed by comparing their relative contribution to the total deviance explained. All analyses were performed on the environment R (R Core Team 2014).

\section{Results}

Mean winter SST showed a latitudinal trend, increasing from north to south (Fig. 2a). Nevertheless, the four areas presented very similar patterns along the time series. The highest values were recorded in $1998\left(15.8{ }^{\circ} \mathrm{C}\right.$ in Minho; $16.2^{\circ} \mathrm{C}$ in Ria de Aveiro and Mondego and $16.9^{\circ} \mathrm{C}$ in Tejo) and the lowest in $2009\left(13.8{ }^{\circ} \mathrm{C}\right.$ in Minho; $14.0{ }^{\circ} \mathrm{C}$ in Ria de Aveiro and Mondego and $15.1{ }^{\circ} \mathrm{C}$ in Tejo). Mean winter rainfall has shown high inter-annual variability (Fig. 2b). Although Minho and Ria de Aveiro had values of rainfall much higher than Mondego and Tejo, the rainiest years were the same in all studied areas: 1996 and 2001. The year of 2001 was also the peak for river drainage (Fig. 2c). The highest river drainage was observed in Tejo, reaching $4310 \times 10^{6} \mathrm{~m}^{3}$ in 2001 , whereas Ria de Aveiro presented the lowest values $\left(<200 \times 10^{6} \mathrm{~m}^{3}\right)$.

Landings of Diplodus spp., Solea spp. and O. vulgaris were higher in the Tejo study area, whereas $S$. officinalis was mainly landed in the area of Ria de Aveiro (Fig. 3). LPUE of both Diplodus spp. and D. labrax in Tejo have increased throughout the time series. On the other hand, landings of P. flesus in the same region have declined and become almost negligible since 2000 .

Goodness-of-fit statistics for the GLMs fitted to time lagged LPUE are presented in Table 2. Estuary was the only explanatory variable in every model. The total explained deviance varied from $23.3 \%$ for P. flesus to $93.48 \%$ for S. officinalis. The models for Solea spp. and $O$. vulgaris also had high percentages of explained deviance 
Diplodus spp.

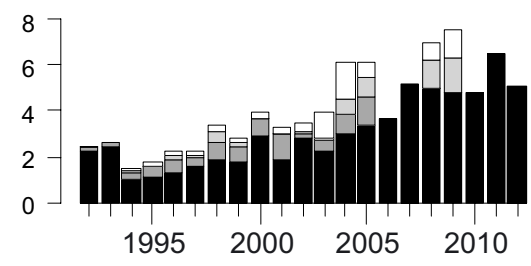

Platichthys flesus

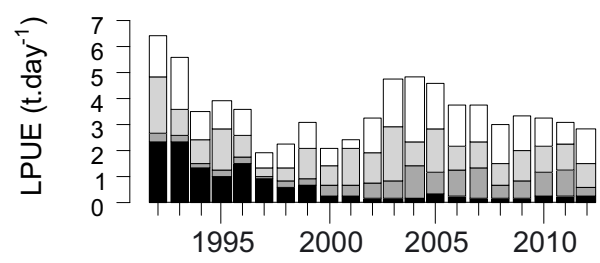

Octopus vulgaris

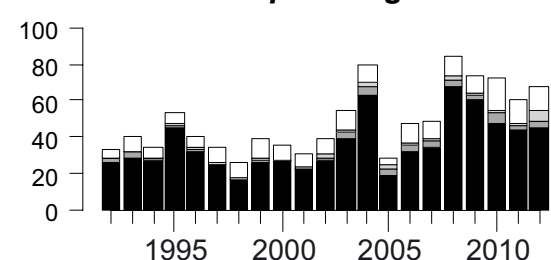

Dicentrarchus labrax

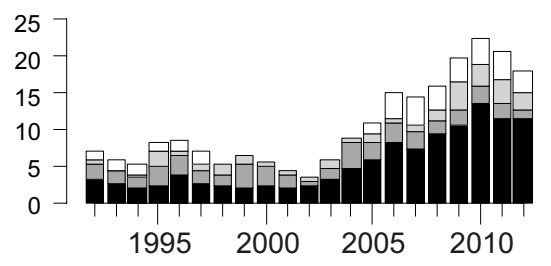

Solea spp.

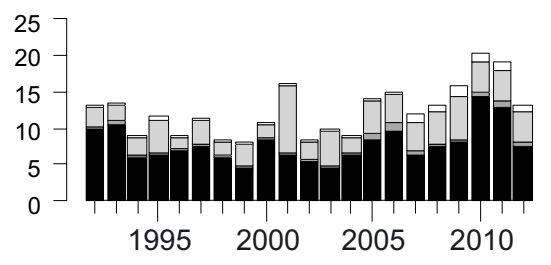

Sepia officinalis

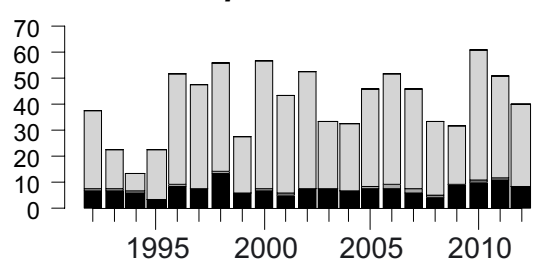

Fig. 3. Annual LPUE of the six studied species landed in the four studied areas (black bars - Tejo; dark gray bars - Mondego; light gray bars Ria de Aveiro; white bars - Minho).

Table 2. Goodness-of-fit statistics for the GLMs fitted to LPUE of each species/group of species considered (\% explained-percentage of the total deviance explained).

\begin{tabular}{|c|c|c|c|c|}
\hline Model & Deviance & $\begin{array}{l}\text { Residual } \\
\text { deviance }\end{array}$ & $\begin{array}{c}\% \\
\text { explained }\end{array}$ & $p$-value \\
\hline $\begin{array}{l}\text { Diplodus spp. } \\
\text { NULL } \\
\text { factor (estuary) } \\
\text { Total explained }\end{array}$ & 62.078 & $\begin{array}{l}146.66 \\
84.58\end{array}$ & $\begin{array}{l}42.32 \\
42.32\end{array}$ & $<0.001$ \\
\hline $\begin{array}{c}\text { Dicentrarchus labra } \\
\text { NULL } \\
\text { factor (estuary) } \\
\text { Total explained }\end{array}$ & 22.55 & $\begin{array}{l}52.25 \\
29.71\end{array}$ & $\begin{array}{l}43.15 \\
43.15\end{array}$ & $<0.001$ \\
\hline $\begin{array}{c}\text { Platichthys flesus } \\
\text { NULL } \\
\text { factor (estuary) } \\
\text { Total explained }\end{array}$ & 9.93 & $\begin{array}{l}42.62 \\
32.69\end{array}$ & $\begin{array}{l}23.30 \\
23.30\end{array}$ & $\begin{array}{l}<0.001 \\
<0.001\end{array}$ \\
\hline $\begin{array}{c}\text { Solea spp. } \\
\quad \text { NULL } \\
\text { factor (estuary) } \\
\text { Total explained }\end{array}$ & 107.86 & $\begin{array}{c}127.60 \\
19.74\end{array}$ & $\begin{array}{l}84.53 \\
84.53\end{array}$ & $<0.001$ \\
\hline $\begin{array}{l}\text { Sepia officinalis } \\
\text { NULL } \\
\text { factor (estuary) } \\
\text { Total explained }\end{array}$ & 345.72 & $\begin{array}{l}369.83 \\
24.116\end{array}$ & $\begin{array}{l}93.48 \\
93.48\end{array}$ & $<0.001$ \\
\hline $\begin{array}{l}\text { Octopus vulgaris } \\
\text { NULL } \\
\text { factor (estuary) } \\
\text { Total explained }\end{array}$ & 125.88 & $\begin{array}{c}169.31 \\
43.43\end{array}$ & $\begin{array}{l}74.35 \\
74.35\end{array}$ & $<0.001$ \\
\hline
\end{tabular}

(84.53\% and $74.35 \%)$, whereas the models obtained for Diplodus spp. and D. labrax explained $42.32 \%$ and $43.15 \%$ of the total deviance, respectively.

\section{Discussion}

The present work analysed coastal fisheries data in four areas near estuaries and could not find an effect of river drainage on landings of the species studied. Not only were the correlations between river drainage and LPUE not significant, but also river drainage was only included as an explanatory variable in the model for landings of Solea spp. The variable estuary was always the best explanatory variable in the models, regardless of the species considered.

Inter-annual and seasonal variations in freshwater flow affect growth, survival and recruitment of fish and invertebrates (Gillson 2011). The resulting changes in distribution and abundance of these species are therefore likely to affect fisheries in coastal areas. In fact, previous works have pointed to an increase in fishery production following higher river runoff (e.g. Darnaude et al. 2004; Le Pape et al. 2003; Salen-Picard et al. 2002). Various mechanisms underlying the relationship between river runoff and fisheries have been proposed, but food availability has most often been considered the main factor, both through increased planktonic production following nutrient loads (Cloern 2001; Moutin et al. 1998) and enrichment in POM in macrobenthic communities (Salen-Picard et al. 2002). A study in the north-western Mediterranean searched for relationships between the river drainage of the Rhone, the benthic 
communities of its delta and landings of $S$. solea in the Gulf of Lions (Salen-Picard et al. 2002). A positive correlation between the Rhone river drainage and landings of S. solea in two nearby fishing ports, with a time lag of 5 years, was found (Salen-Picard et al. 2002). As the authors observed that floods caused pulses of organic matter and peaks of polychaetes, with different time lags, they have linked the increase in landings to an increase in food resources following higher river drainage (Salen-Picard et al. 2002). For the same region, it has been stated that a significant proportion of flesh carbon in S. solea came from terrestrial origin (Darnaude et al. 2004). According to these studies, higher landings would be expected in years following higher river drainage, with each species' response depending on a time lag reflecting age at recruitment (Darnaude 2005). In the Bay of Biscay, the availability of estuarine nursery grounds, and consequently the production of juvenile $S$. solea, has been shown to be influenced by the extent of the riverine plume front (Le Pape et al. 2003).

The variability of the relationships between river flow and landings of fish and invertebrates may be related to factors such as geographic location (Gillanders and Kingsford 2002) or estuarine geomorphology (Saintilan 2004). For the same species, relationships between freshwater flow and landings can be positive, negative, or inconsistent among regions (Gillson 2011). In fact, the present work has used time lags based on age at first maturity and has not found a significant relationship of landings with river drainage. The influence of the river Tejo extends up to $30 \mathrm{~km}$ from the river mouth in low flow conditions, where terrestrial POM accounts for $24 \%$ of the total POM (Vinagre et al. 2011). Therefore, the extent of the influence of terrestrial carbon from the Tejo under low flow conditions is much larger than that found for the river Rhone, where at approximately $30 \mathrm{~km}$ from the river mouth the percentage of terrestrial carbon was null (Hermand et al. 2008). As the influence of the Tejo in coastal areas remains particularly high even in low flow conditions, it is possible that the difference in flow in wetter years is not sufficiently large to induce ecological responses which would lead to higher landings of the studied species. On the other hand, relationships between river drainage and fisheries production will depend on how strongly a food web relies on nutrients and organic matter of river origin (Gillson 2011). Semi-enclosed coastal regions, such as the Mediterranean Sea, receive limited nutrient supplies from oceanic currents or upwelling events and therefore fisheries production may be more dependent on river nutrients (Gillson 2011), as was found in previously mentioned works (Darnaude et al. 2004; Salen-Picard et al. 2002). In the Western Portuguese coast, however, an upwelling regime is of particular importance for the richness and diversity of the coastal ecosystem and for fisheries (Lemos and Sansó 2006) and thus variations in river flow observed in the present work did not result in higher landings of the studied species.

The effect of upwelling on pelagic fish fisheries has received particular attention (Borges et al. 2003; Santos et al. 2001, 2004). Several pelagic fish species have their reproductive strategy adapted to coastal upwelling systems. They spawn in winter, when the northerly winds that cause upwelling are weaker, thus reducing the risk of Ekman transport offshore and ensuring inshore transport and larval retention
(Nunes et al. 2011; Stratoudakis et al. 2007). The increase in productivity from summer upwelling will later benefit the feeding of the larvae (Santos et al. 2001). Although the traditional upwelling season is between April and September, northerly winds that favour this phenomenon are recurrent in the Portuguese coast throughout the year (Huthnance et al. 2002). When winter upwelling occurs, it will likely transport eggs and larvae offshore, resulting in high mortality rates. These events have already been reported for sardine (Borges et al. 2003; Santos et al. 2001) and may also occur with other species. The recruitment of coastal species is also dependent on other factors, such as temperature (Rijnsdorp et al. 1995), predation (Bailey and Houde 1989) or food availability (Cushing 1972), and the interaction of different factors (Santos et al. 2004). The complexity of the coastal upwelling on the Portuguese coast, and its possible interaction with all other factors affecting recruitment, makes the task of detecting the effects of river drainage on landings particularly difficult.

Flatfish landings have been increasing in Portugal, where their fisheries have a high socio-economic importance (Teixeira and Cabral 2009). Sole landings are particularly relevant in the central coast, as $60 \%$ of total sole landings occur there (Batista et al. 2009; Teixeira and Cabral 2009; Teixeira et al. 2011). In fact, in the present work, landings of this group of species were higher in the Tejo study area. Although once abundant in the Tejo, P. flesus is now restricted to the northern estuaries, due to increasing SST in the Portuguese coast, where this species has its southern distribution limit (Cabral et al. 2001, 2007; Vinagre et al. 2009). The increasing SST has also been indicated as the reason for the increasing abundance of $D$. bellottii in the Tejo estuary, as this southern species finds its northern limit in the Portuguese coast (Cabral et al. 2001; Vinagre et al. 2009). The increasing abundance of this species may be responsible for the higher and increasing landings of Diplodus spp. in the Tejo area.

The highest landings of D. labrax were observed in the Tejo area and have been increasing since the 2000s. Although a positive correlation of abundance of $D$. labrax juveniles with river drainage in the Tejo estuary has previously been reported (Vinagre et al. 2009), landings have not shown such a relationship with river drainage. The fact that the same authors have not found a trend in D. labrax abundance in the Tejo estuary over time (Vinagre et al. 2009) may indicate that the increasing trend observed in landings is probably due to the growing interest of consumers in this species.

O. vulgaris is currently the second most important target in Portuguese fisheries in terms of value (Pilar-Fonseca et al. 2014). In the present work, landings of this species were highest in the Tejo area. $O$. vulgaris has a short life cycle of 12-18 months and reaches minimum landing weight at 9-10 months-old (Katsanevakis and Verriopoulos 2006b). Moreno et al. (2014) found that in the southwestern coast of Portugal octopus pre-recruits aggregated in recruitment grounds close to the Tejo and Sado estuaries. O. vulgaris is stenohaline in all life stages and does not reside in estuaries, but the authors hypothesised that it may take advantage of the high productivity of estuarine systems by living in their vicinity (Moreno et al. 2014). Bottom salinity and river runoff have been considered the environmental variables with most impact 
on pre-recruit distribution and abundance on the Portuguese western coast (Moreno et al. 2014). Gamito et al. (2015) analysed 86 years of fisheries data in an area south of the Tejo and did not find a relationship between rainfall and $O$. vulgaris landings. However, a significant effect of SST was observed (Gamito et al. 2015). The present work did not find significant relationships between river runoff and landings of this species in any of the coastal areas studied.

S. officinalis was mainly landed in the Ria de Aveiro area. Spawning, which only occurs once in the life span of cuttlefish, usually takes place in shallow waters inshore, such as estuarine systems, from February to June. In late autumn, when temperature starts to decrease, they migrate to nearby coastal waters (Neves et al. 2009; Wang et al. 2003). Ria de Aveiro is a shallow coastal lagoon system with large intertidal areas, where $S$. officinalis finds adequate conditions for spawning (Pereira et al. 2009). The variable month was also included in the model, which would likely be explained by the seasonality of cuttlefish fisheries, which target $S$. officinalis spawners inside estuarine systems (Batista et al. 2009; Gamito et al. 2015). No relationship between river drainage and landings of $S$. officinalis was found. As this species was mainly landed in the area with the lowest river drainage in the present study, it is possible that the impact of river drainage on cuttlefish in that area is not a determinant factor on landings.

Most fisheries production worldwide is associated with three nutrient-enrichment processes: coastal upwelling, tidal mixing, and land-based runoff, including major river outflow (Caddy and Bakun 1994).

Climate-induced changes in Portuguese fisheries have already been reported (Gamito et al. 2013, 2015; Teixeira et al. 2014). There has been a reduction in the intensity and frequency of rainfall in Portugal (IPCC 2007), which will also decrease the drainage of Portuguese rivers into coastal areas. Although the present work has not found a relationship between river drainage and landings of the studied species, future decreases in river drainage may have an impact on fisheries. River flow influences a myriad of environmental factors that are determinant for the habitat characteristics of estuarine and coastal systems, such as rates of sediment delivery, salinity, turbidity and temperature (Gillson 2011). In fact, temperature in the Portuguese coast has been increasing (Belkin 2009; IPCC 2007), with observed effects on fisheries (Gamito et al. 2013, 2015; Teixeira et al. 2014). However, the combined effect of changes in temperature and river flow in the future remains unknown. River plumes may also have a crucial role as cues of the proximity of nursery areas for fish larvae (Vinagre et al. 2009). S. solea, S. senegalensis and D. labrax larval immigration into the Tejo estuary has been found to be positively influenced by river drainage (Vinagre et al. 2007, 2009). Although the present work has not found a relationship between river drainage and landings of these species, the predicted decrease in rainfall (Miranda et al. 2002) could potentially lead to a decrease in larval immigration into estuaries in the future, with consequences for fisheries.

The present study used time-lags based on the available knowledge on age at first maturity, assuming that the effects of environmental variables are stronger on early life stages. However, it is possible that events in later life stages of this species could affect fisheries landings without being detected in the present study. Longer time series and data on juvenile abundance in estuaries could possibly bring new insight to the subject of influence of river drainage on fisheries. However, as it is often the case when dealing with long-term studies, those data were not available for the present study.

Acknowledgements. This study had the support of Fundação para a Ciência e Tecnologia (FCT), through the strategic project UID/MAR/04292/2013 granted to MARE, the grants awarded to R. Gamito (SFRH/BD/78363/2011) and C.M. Teixeira (SFRH/BPD/62986/2009) and the project PTDC/AAG-REC/ $2139 / 2012$.

\section{References}

Bailey K.M., Houde E.D., 1989, Predation on eggs and larvae of marine fishes and the recruitment problem. Adv. Mar. Biol. 25, 1-83.

Batista M.I., Teixeira C.M., Cabral H.N., 2009, Catches of target species and bycatches of an artisanal fishery: The case study of a trammel net fishery in the Portuguese coast. Fish. Res. 100, 167177.

Belkin I.M., 2009, Rapid warming of Large Marine Ecosystems. Prog. Oceanogr. 81, 207-213.

Benchalel W., Kara M.H., 2013, Age, growth and reproduction of the white seabream Diplodus sargus sargus (Linneaus, 1758) off the eastern coast of Algeria. J. Appl. Ichthyol. 29, 64-70.

Borges M.F., Santos A.M.P., Crato N., Mendes H., Mota B., 2003, Sardine regime shifts off Portugal: a time series analysis of catches and wind conditions. Sci. Mar. 67, 235-244.

Brander K.M., 2007, Global fish production and climate change. Proc. Natl. Acad. Sci. USA 104, 19709-19714.

Briggs J.C., 1974, Marine zoogeography. McGraw-Hill, New York.

Brown C.J., Fulton E.A., Hobday A.J., Matear R.J., Possingham H.P., Bulman C., Christensen V., Forrest R.E., Gehrke P.C., Gribble N.A., Griffiths S.P., Lozano-Montes H., Martin J.M., Metcalf S., Okey T.A., Watson R., Richardson A.J., 2010, Effects of climatedriven primary production change on marine food webs: implications for fisheries and conservation. Glob. Chang. Biol. 16, 1194 1212.

Cabral H., Vasconcelos R., Vinagre C., Franca S., Fonseca V., Maia A., Reissantos P., Lopes M., Ruano M., Campos J., 2007, Relative importance of estuarine flatfish nurseries along the Portuguese coast. J. Sea Res. 57, 209-217.

Cabral H.N., Costa M.J., Salgado J.P., 2001, Does the Tagus estuary fish community reflect environmental changes? Clim. Res. 18, 119-126.

Caddy J.F., Bakun A., 1994, A tentative classification of coastal marine ecosystems based on dominant processes of nutrient supply. Ocean Coast. Manag. 23, 201-211.

Cloern J.E., 2001, Our evolving conceptual model of the coastal eutrophication problem. Mar. Ecol. Prog. Ser. 210, 223-253.

Cushing D.H., 1972, The production cycle and the numbers of marine fish. Symposium Zoological Society of London 29, 213-232.

Darnaude A.M., 2005, Fish ecology and terrestrial carbon use in coastal areas: implications for marine fish production. J. Anim. Ecol. 74, 864-876.

Darnaude A.M., Salen-Picard C., Polunin N.V.C., Harmelin-Vivien M.L., 2004, Trophodynamic linkage between river runoff and coastal fishery yield elucidated by stable isotope data in the Gulf of Lions (NW Mediterranean). Oecologia 138, 325-32. 
Failler P., 2007, Future prospects for fish and fishery products. 4. Fish consumption in the European Union in 2015 and 2030. Part 1. European overview. FAO Fisheries Circular. No. 972/4, Part 1. FAO, Rome.

Gamito R., Teixeira C.M., Costa M.J., Cabral H.N., 2013, Climateinduced changes in fish landings of different fleet components of Portuguese fisheries. Reg. Environ. Chang. 13, 413-421.

Gamito R., Teixeira C.M., Costa M.J., Cabral H.N., 2015, Are regional fisheries' catches changing with climate? Fish. Res. 161, 207-216.

Gillanders B.M., Kingsford M.J., 2002, Impact of changes in flow of freshwater on estuarine and open coastal habitats and the associated organisms. Oceanogr. Mar. Biol. 40, 233-309.

Gillson J., 2011, Freshwater flow and fisheries production in estuarine and coastal systems: where a drop of rain is not lost. Rev. Fish. Sci. 19, 168-186.

Gonçalves J.M.S., Bentes L., Coelho R., Correia C., Lino P.G., Monteiro C.C., Ribeiro J., Erzini K., 2003, Age and growth, maturity, mortality and yield-per-recruit for two banded bream (Diplodus vulgaris Geoffr.) from the south coast of Portugal. Fish. Res. 62, 349-359.

Gordoa A., Moli B., 1997, Age and growth of the sparids Diplodus vulgaris, D. sargus and D. annularis in adult populations and the differences in their juvenile growth patterns in the north-western Mediterranean Sea. Fish. Res. 33, 123-129.

Halpern B.S., Walbridge S., Selkoe K.A., Kappel C. V, Micheli F., D’Agrosa C., Bruno J.F., Casey K.S., Ebert C., Fox H.E., Fujita R., Heinemann D., Lenihan H.S., Madin E.M.P., Perry M.T., Selig E.R., Spalding M., Steneck R., Watson R., 2008, A global map of human impact on marine ecoystems. Science 319, 948 952.

Hermand R., Salen-Picard C., Alliot E., Degiovanni C., 2008, Macrofaunal density, biomass and composition of estuarine sediments and their relationship to the river plume of the Rhone River (NW Mediterranean). Estuar. Coast. Shelf Sci. 79, 367-376.

Huthnance J.M., Aken H.M. Van, White M., Barton E.D., Le Cann B., Coelho E.F., Fanjul E.A., Miller P., Vitorino J., 2002, Ocean margin exchange - water flux estimates. J. Mar. Syst. 32, 107137.

IPCC, 2007, Climate Change 2007: The Physical Science Basis. Contribution of Working Group I to the Fourth Assessment Report of the Intergovernmental Panel on Climate Change, Climate Change 2007: The Physical Science Basis. Contribution of Working Group I to the Fourth Assessment Report of the Intergovernmental Panel on Climate Change. Cambridge University Press, Cambridge, UK and New York, NY, USA.

Katsanevakis S., Verriopoulos G., 2006a, Seasonal population dynamics of Octopus vulgaris in the eastern Mediterranean. ICES J. Mar. Sci. 63, 151-160.

Katsanevakis S., Verriopoulos G., 2006b, Modelling the effect of temperature on hatching and settlement patterns of meroplanktonic organisms: the case of the octopus. Sci. Mar. 70, 699-708.

Le Pape O., Chauvet F., Désaunay Y., Guérault D., 2003, Relationship between interannual variations of the river plume and the extent of nursery grounds for the common sole (Solea solea, L.) in Vilaine Bay. Effects on recruitment variability. J. Sea Res. 50, 177-185.

Lemos R.T., Sansó B., 2006, Spatio-temporal variability of ocean temperature in the Portugal Current System. J. Geophys. Res. Ocean. 111, C04010.

Maynou F., Demestre M., Sánchez P., 2003, Analysis of catch per unit effort by multivariate analysis and generalised linear models for deep-water crustacean fisheries off Barcelona (NW Mediterranean). Fish. Res. 65, 257-269.
McCullagh P., Nelder J.A., 1983, Generalized Linear Models. Chapman \& Hall, London.

Miranda P.M.A., Coelho F.E.S., Tomé A.R., Valente M.A., 2002, 20th Century Portuguese climate and climate scenarios. In: Santos F.D., Forbes K., Moita R. (Eds.), Climate Change in Portugal. Scenarios, Impacts and Adaptation Measures - Project SIAM. Gradiva, Lisboa, pp. 27-83.

Moreno A., Lourenço S., Pereira J., Gaspar M.B., Cabral H.N., Pierce G.J., Santos A.M.P., 2014, Essential habitats for prerecruit Octopus vulgaris along the Portuguese coast. Fish. Res. $152,74-85$.

Moutin T., Raimbault P., Golterman H.L., Coste B., 1998, The input of nutrients by the Rhône river into the Mediterranean Sea: recent observations and comparison with earlier data. Hydrobiologia 373/374, 237-246.

Myers R.A., Pepin P., 1990, The robustness of lognormal-based estimators of abundance. Biometrics 46, 1185-1192.

Neves A., Cabral H., Sequeira V., Figueiredo I., Moura T., Gordo L.S., 2009, Distribution patterns and reproduction of the cuttlefish, Sepia officinalis in the Sado estuary (Portugal). J. Mar. Biol. Assoc. UK 89, 579-584.

Nunes C., Silva A., Soares E., Ganias K., 2011, The use of hepatic and somatic indices and histological information to characterize the reproductive dynamics of Atlantic sardine Sardina pilchardus from the Portuguese coast. Mar. Coast. Fish. 3, 127-144.

Pawson M.G., Kupschus S., Pickett G.D., 2007, The status of sea bass (Dicentrarchus labrax) stocks around England and Wales, derived using a separable catch-at-age model, and implications for fisheries management. ICES J. Mar. Sci. 64, 346-356.

Pereira P., Raimundo J., Vale C., Kadar E., 2009, Metal concentrations in digestive gland and mantle of Sepia officinalis from two coastal lagoons of Portugal. Sci. Total Environ. 407, 1080-1088.

Pilar-Fonseca T., Campos A., Pereira J., Moreno A., Lourenço S., Afonso-Dias M., 2014, Integration of fishery-dependent data sources in support of octopus spatial management. Mar. Policy $45,69-75$.

R Core Team, 2014, R: A language and environment for statistical computing. R Foundation for Statistical Computing, Vienna, Austria. http://www.R-project.org/.

Rijnsdorp A.D., Berghahn R., Miller J.M., Van Der Veer H.W., 1995, Recruitment mechanisms in flatfish: What did we learn and where do we go? Netherlands J. Sea Res. 34, 237-242.

Saintilan N., 2004, Relationships between estuarine geomorphology, wetland extent and fish landings in New South Wales estuaries. Estuar. Coast. Shelf Sci. 61, 591-601.

Salen-Picard C., Arlhac D., 2002, Long-term changes in a Mediterranean benthic community: relationships between the polychaete assemblages and hydrological variations of the Rhône river. Estuaries 25, 1121-1130.

Salen-Picard C., Darnaude A., Arlhac D., Harmelin-Vivien M., 2002, Fluctuations of macrobenthic populations: a link between climate-driven river run-off and sole fishery yields in the Gulf of Lions. Oecologia 133, 380-388.

Santos A.M.P., Borges M. de F., Groom S., 2001, Sardine and horse mackerel recruitment and upwelling off Portugal. ICES J. Mar. Sci. 58, 589-596.

Santos A.M.P., Peliz A., Dubert J., Oliveira P.B., Angélico M.M., Ré P., 2004, Impact of a winter upwelling event on the distribution and transport of sardine (Sardina pilchardus) eggs and larvae off western Iberia: a retention mechanism. Cont. Shelf Res. 24, 149165.

Santos F.D., 2006, Climate change in the beginning of the 21st century. In: Santos FD, Miranda P (eds) Climate change in Portugal. 
Scenarios, impacts and adaptation measures - Project SIAM II, Gradiva, Lisbon

Simenstad C.A., Wissmar R.C., 1985, Delta-C-13 evidence of the origins and fates of organic carbon in estuarine and nearshore food webs. Mar. Ecol. Prog. Ser. 22, 141-152.

Stefánsson G., 1996, Analysis of groundfish survey abundance data?: combining the GLM and delta approaches. ICES J. Mar. Sci. 53, 577-588.

Stratoudakis Y., Coombs S., Lanzós A.L., Halliday N., Costas G., Caneco B., Franco C., Conway D., Santos M.B., Silva A., Bernal M., 2007, Sardine (Sardina pilchardus) spawning seasonality in European waters of the northeast Atlantic. Mar. Biol. 152, 201212.

Sumaila U.R., Cheung W.W.L., Lam V.W.Y., Pauly D., Herrick S., 2011, Climate change impacts on the biophysics and economics of world fisheries. Nat. Clim. Chang. 1, 449-456.

Teixeira C.M., Cabral H.N., 2009, Time series analysis of flatfish landings in the Portuguese coast. Fish. Res. 96, 252-258.

Teixeira C.M., Cabral H.N., 2010, Comparative analysis of the diet, growth and reproduction of the soles, Solea solea and Solea senegalensis, occurring in sympatry along the Portuguese coast. J. Mar. Biol. Assoc. UK 90, 995-1003.

Teixeira C.M., Pinheiro A., Cabral H.N., 2009, Feeding ecology, growth and sexual cycle of the sand sole, Solea lascaris, along the Portuguese coast. J. Mar. Biol. Assoc. UK 89, 621-627.
Teixeira C.M., Batista M.I., Cabral H.N., 2010, Diet, growth and reproduction of four flatfishes on the Portuguese coast. Sci. Mar. 74, 223-233.

Teixeira C.M., Batista M.I., Cabral H.N., 2011, Landing profiles and typologies of flatfish fisheries on the Portuguese coast. Aquat. Living Resour. 24, 169-182.

Teixeira C.M., Gamito R., Leitão F., Cabral H.N., Erzini K., Costa M.J., 2014, Trends in landings of fish species potentially affected by climate change in Portuguese fisheries. Reg. Environ. Chang. 14, 657-669.

Vinagre C., Costa M., Cabral H., 2007, Impact of climate and hydrodynamics on sole larval immigration towards the Tagus estuary, Portugal. Estuar. Coast. Shelf Sci. 75, 516-524.

Vinagre C., Santos F.D., Cabral H.N., Costa M.J., 2009, Impact of climate and hydrology on juvenile fish recruitment towards estuarine nursery grounds in the context of climate change. Estuar. Coast. Shelf Sci. 85, 479-486.

Vinagre C., Máguas C., Cabral H.N., Costa M.J., 2011, Spatial variation in river runoff into a coastal area - An ecological approach. J. Sea Res. 65, 362-367.

Wang J., Pierce G.J., Boyle P.R., Denis V., Robin J., Bellido J.M., 2003, Spatial and temporal patterns of cuttlefish (Sepia officinalis) abundance and environmental influences - a case study using trawl fishery data in French Atlantic coastal, English Channel, and adjacent waters. ICES J. Mar. Sci. 60, 1149-1158. 